WSRC-TR-99-00244-TL, Revision 0

Keywords: DWPF,

CST, Frit,

Particle

Size

Retention: Permanent

August 30, 1999

S. F. Piccolo, Team Leader

Salt Disposition Systems Engineering Team

\title{
CST/FRIT SETTLING, CST PARTICLE SIZE REDUCTION AND CST LOADING (U)
}

The attached report summarizes the bench-scale activities performed; to load crystalline silicotitanate (CST) resin with noble metals for use in hydrogen generation studies, and determine the hydrodynamic character of CST compared to Frit 202 for further mixing and sampling ștudies.

The salt disposition team requested that; the effect of CST resin loaded with noble metals on the maximum hydrogen generation rate produced during the DWPF melter feed preparation processes, and determine what particle size of CST resin would be needed to allow mixing and sampling of melter feed with the existing equipment.

Loading of the CST resin was performed using a small volume of salt at the nominal salt concentration with cesium and potassium levels increased to account for the large number of column volumes that the CST columns are expected to treat. Cesium adsorption kinetics indicated a rapid up-take of cesium, but only small amounts of noble metals were removed from solution.

The experimental results indicate that reducing the size of the CST to that comparable to the frit (80-200 mesh) will yield similar hydrodynamic character. Results indicate that the particle size of distribution of the CST can reduced by re-circulating a CST slurry through a centrifugal pump, but the efficiency of the size reduction per pass is small.

If there are additional questions regarding the attached report, please contact M. A. Baich at 7-7692.

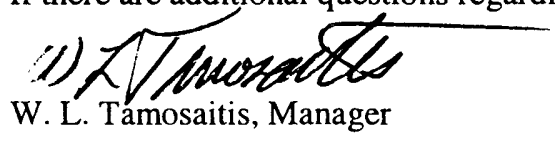

SRTC-Waste Processing Section 


\section{CST/FRIT SETTLING, CST PARTICLE SIZE REDUCTION AND CST LOADING (U)}

M. A. Baich

Westinghouse Savannah River Company

Savannah River Technology Center

Aiken, South Carolina

Westinghouse Savannah River Company

Savannah River Site

Aiken, SC 29808

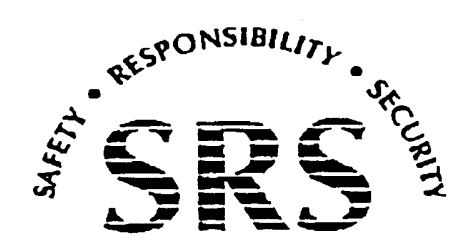

SAVANNAH RIVER SITE

PREPARED FOR THE U.S. DEPARTMENT OF ENERGY UNDER CONTRACT NO. DE-AC09-96SR18500 


\section{DISCLAIMER}

This report was prepared as an account of work sponsored by an agency of the United States Government. Neither the United States Government nor any agency thereof, nor any of their employees, makes any warranty, express or implied, or assumes any legal liability or responsibility for the accuracy, completeness, or usefulness of any information, apparatus, product or process disclosed, or represents that its use would not infringe privately owned rights. Reference herein to any specific commercial product, process or service by trade name, trademark, manufacturer, or otherwise does not necessarily constitute or imply its endorsement, recommendation, or favoring by the United States Government or any agency thereof. The views and opinions of authors expressed herein do not necessarily state or reflect those of the United States Government or any agency thereof.

This report has been reproduced directly from the best available copy.

Available for sale to the public, in paper, from: U.S. Department of Commerce, National Technical Information Service, 5285 Port Royal Road, Springfield, VA 22161, phone: (800) 553-6847

fax: (703) 605-6900

email: orders@ntis.fedworld.gov

online ordering: http://www.ntis.gov/ordering.htm

Available electronically at http://www.doe.gov/bridge

Available for a processing fee to U.S. Department of Energy and its contractors, in paper, from: U.S. Department of Energy, Office of Scientific and Technical Information, P.O. Box 62, Oak Ridge, TN 37831-0062, phone: (865) 576-8401

fax: (865) 576-5728

email: reports@adonis.osti.gov 
WSRC-TR-99-00244, Revision 0

Keywords: DWPF, CST, Frit, Particle Size

Retention: Permanent

CST/FRIT SETTLING, CST PARTICLE SIZE REDUCTION AND CST LOADING (U)

\section{A. Baich}

Westinghouse Savannah River Company

Savannah River Technology Center

Ailren, South Carolina

Publication Date: July 30, 1999 


\section{Approvals}

manh Bach

M. A. Baich, Author, Immobilization Technology Section

\section{trant Almat}

F. G. Smith, III, Technical Reviewer, Immobilization Technology Section

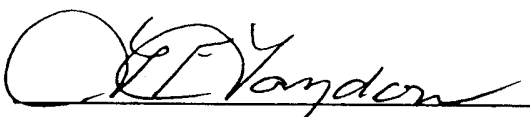

L. F. Landon, Manager Process Technology Development Group Immobilization Technglogy Seckion
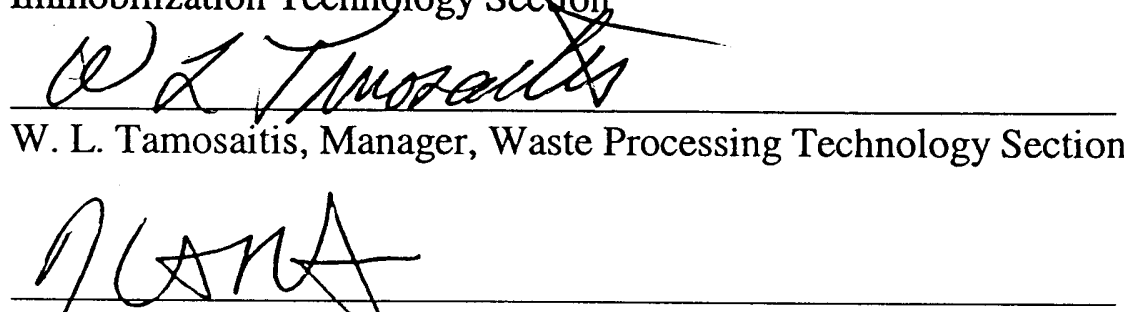

K. 5. Rueter, HLWM, Chief Engineer

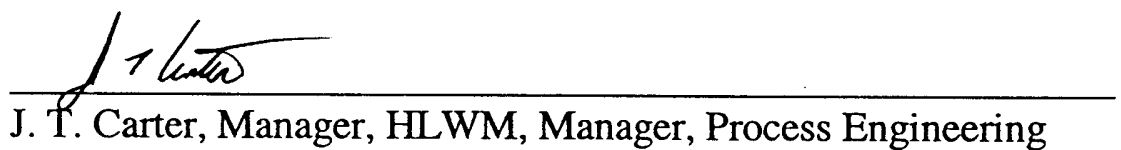

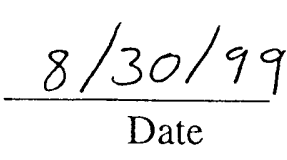

$\frac{9 / 8 / 99}{\text { Date }}$
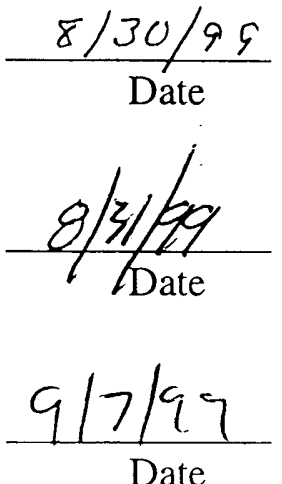

Date

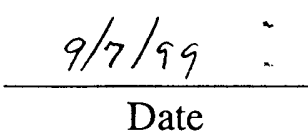

Westinghouse Savannah River Companỳ

Savannah River Site

Aiken, SC 29808

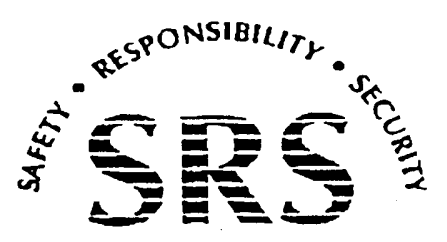

PREPARED FOR THE U.S. DEPARTMENT OF ENERGY UNDER CONTRACT NO. DE-AC09-96SR18500 


\section{EXECUTIVE SUMMARY}

- Reducing the particle distribution of as-received CST to that of Frit 202 (80-200 mesh) will result in CST hydrodynamic properties comparable to that of Frit 202.

- CST can absorb small quantities of soluble noble metal species which may or may not be catalytic in the production of hydrogen during sludge feed preparation.

- As-received CST particle size can be reduced by exposure to a high shear environment (such as a centrifugal pump). However, vendors are available that sell equipment for the specific purpose of reducing the particle size of slurries.

- During unloading of the 4" CST column, it was found that if the column remains flooded, the slurry of CST flows very well. Slurry flow from a $1 / 2$ " ball valve (flow opening about $3 / 8$ ") could be started and stopped without becoming plugged. 
Immobilization Technology Section

WSRC-TR-99-00244

Savannah River Technology Center.

Revision 0

Westinghouse Savannah River Company

\section{LIST OF FIGURES}

Figure 1. Experimental Setup for CST and Frit Settling Studies

Figure 2. Particle Size Distribution of Frit 202

Figure 3. Particle Size Distribution of As-Received Batch 4 CST

Figure 4. Particle Size Distribution of As-Received Batch 5 CST

Figure 5. Settling Time Comparison between Frit 202 and As-Received Batch 4 CST

Figure 6. Percent Bed Expansion versus Column Flow Rate for Batch 4 CST

Figure 7. Particle Size Distribution of As-Received Batch 4 CST (Pumped for 8 Hours)

Figure 8. CST Grinding and Classification Setup

Figure 9. Particle Size Analysis of Batch Grinding Experiments

Figure 10. Noble Metals Conc. versus Time for Batch Kinetics Study

Figure 11. Small Scale CST Loading Setup

Figure 12. Four Inch Diameter CST Loading Column

Figure 13. Noble Metals Concentration in Salt Solution versus Time for CST Loading Batch 2 


\section{LIST OF TABLES}

Table I.

Table II.

Table III.

Table IV.

Table V.
Noble Metals Loading on CST

CST Loading Salt Solution Makeup for Bench-Scale Process Simulations CST Cesium Loading Rate Data

CST Loading Salt Solution Makeup for Pilot-Scale Process Simulations CST Loading Salt Solution Analysis 


\section{INTRODUCTION}

Crystalline Silicotitanate (CST) resin was selected as one of two alternatives to the In-Tank Precipitation Process (ITP) for removal of cesium from the salt waste at Savannah River Site. The proposed salt waste treatment process using CST would involve passing a filtered salt waste through a fixed bed of CST resin. The CST would remove the cesium from the salt waste by ion exchange and the decontaminated salt would be incorporated into the Saltstone Process. The loaded resin would then be sent to the Defense Waste Processing Facility (DWPF) for incorporation into the waste glass product.

Concerns have been raised as to whether as-received CST resin (particle size distribution 30-60 mesh), can be suspended by the existing mixing systems in the DWPF and whether a melter feed containing CST can be representatively sampled with the Hydragard sampler and associated transfer systems. Thoughts are that if the CST is shown to have the same hydrodynamic characteristics as the DWPF frit, it will exhibit similar mixing and sampling characteristics. Another concern is whether or not CST resin can adsorb soluble noble metals from the salt solution and form a solid supported catalyst, which could potentially lead to increased hydrogen production rates in the DWPF Chemical Process Cell.

This report documents the results of laboratory investigations into the hydrodynamic character of the CST compared to DWPF frit and discusses attempts to alter the hydrodynamic character of . the CST. CST's ability to adsorb noble metals was also investigated. It was found that CST has the ability to adsorb some noble metals, which necessitated the production of loaded CST for both bench-scale and pilot scale melter feed prep process simulations to determine if increased hydrogen production would occur during the DWPF process. This report documents the manner in which this material was produced.

\section{DISCUSSION}

\section{CST Settling Studies}

\section{Test Equipment Configuration}

Figure 1 presents a drawing of the equipment used to determine the bed expansion and settling character of CST and frit. The glass column was $2.54 \mathrm{~cm}$ in diameter and $50 \mathrm{~cm}$ in height and was filled with solids to a depth of around $20 \mathrm{~cm}$. The pump was run at a set flow rate to expand the bed of solids. The flow rate was limited by the degree of bed expansion observed for each solid investigated. Bed expansion is defined to be:

$$
\% \text { Bed Expansion }=100 \frac{\text { Height of Expanded Bed }- \text { Settled Bed Height }}{\text { Settled Bed Height }}
$$


Initial and final bed heights were recorded. The pump was then stopped and the time for the bed to collapse to its initial height was recorded.

The effect of solution $\mathrm{pH}$ was also investigated. Settling times and bed expansion results performed with Frit 202 in water $(\mathrm{pH}=10.18)$ were found to be no different from those obtained when the solution $\mathrm{pH}$ was adjusted with formic acid to a $\mathrm{pH}$ of 2.9. Similar results were obtained with CST when the $\mathrm{pH}$ was adjusted with sodium hydroxide from a $\mathrm{pH}$ of 4.2 to a $\mathrm{pH}$ of 11.2 . Based upon these results, adjustments of solution $\mathrm{pH}$ were discontinued in subsequent tests.

\section{Test Results ${ }^{I}$}

Figures 2, 3, and 4 show the particle size distribution of Frit 202 and Batch 4 and Batch 5 asreceived CST, respectively. Figure 5 presents a comparison of settling times for as-received Batch 4 CST and Frit 202. At the same relative bed expansion, the CST settled almost an order of magnitude faster than the frit. Thus, it is postulated that DWPF process vessel mixing systems may not be capable of achieving a homogeneous slurry of sludge, frit and as-received CST particles. This will be tested in Thermal Fluids Laboratory (TFL) experiments where DWPF mixing conditions will be simulated. In an attempt to determine what CST particle size range would have similar hydrodynamic characteristics as the frit, samples of CST were ground and sieved. Various mesh size cuts were tested for settling time and bed expansion. Results indicated that a CST mesh size cut similar to that of the Frit 202 (80-200 mesh) would have comparable hydrodynamic properties. Figure 6 presents a comparison of the bed expansion characteristics of Frit 202 with various mesh cuts of CST.

The results presented above indicate that similar hydrodynamic properties of CST can be obtained by reducing the size of the CST resin. However, operation of a fixed bed of CST in the $-80+200$ mesh size range would lead to excessive pressure drop and likely prohibitive solids loss from the bed.

\section{CST Particle Size Reduction}

The size of the as-received CST resin has been fixed based upon ion exchange bed pressure drop at 30-60 mesh. Processing of the spent CST resin in DWPF will likely require reducing the size of the CST to ensure adequate mixing and representative sampling. Studies have shown (Ref. 1) that CST is friable in a high sheer environment like a centrifugal pump. A 10-liter tank with a slurry recirculation loop (flow $\sim 2 \mathrm{gpm}$ ) was set up in an attempt to determine the pumping time required to reduce the particle size of a $10 \mathrm{wt} \%$ as-received CST slurry. A sample of the resulting CST slurry after approximately 8 hours pumping time was analyzed for solid particle size distribution. Figure 7 presents these results. Results indicate that $57 \%$ of the CST was reduced in size below 80 mesh, but a significant fraction (43\%) was unchanged. It is thought that the degree

\footnotetext{
${ }^{1}$ The UOP CST Lot \# for Batch 4 and Batch 5 was: 999098810004 and 999098810005 , respectively.
} 
of mixing in the tank may have limited the actual number of passes through the pump that the solids were subjected to and therefore the degree of size reduction. Figure 7 also presents the particle size distribution for CST which was boiled in caustic sludge supernatant for 30 hours to simulate a SRAT/SME cycle.

Based upon these results, an alternative tank configuration was setup to size reduce and classify the CST particles. Figure 8 presents a drawing of this experimental setup. The glass vessel contains a small inner section into which the solids are introduced. Not all of the solids were added at once to prevent plugging the inlet to the pump. This inner section feeds directly to the centrifugal pump. A second feed (light end) to the pump comes from the annular space between the inner and outer vessels. By controlling the light end flow, the maximum size of the particles floated over the edge of the inner vessel can be controlled. The annular space provides a semistagnant volume in which solids of the desired size may settle and accumulate. Larger particles remain in the inner vessel until reduced in size and carried over the edge of the inner vessel. Particles of a known size $(-80+200$ mesh) were used to determine the light end flow, which would carry particles of this size over the inner column. Using this setup, 1.5 liters of a $10 \mathrm{wt} \%$ slurry of as-received CST in water was reduced in particle size in less than an hour. Figure 9 presents the particle size analysis for two batches run in this configuration.

\section{Noble Metals Adsorption by CST}

In an effort to determine the degree to which CST can adsorb noble metals, six samples of CST. ( $\sim 5$ grams) were combined with filtered salt solution ( $\sim 16$ grams) containing noble metals and * placed on a shaker table. One sample was removed, filtered, and analyzed each day over a sixday period. Figure 10 presents the noble metals analysis of the filtered material. Experimental results are summarized in Table I. This table shows that CST can adsorb some amount of each of the noble metals present in filtered salt solution, which potentially could result in increased catalytic activity for the production of hydrogen during DWPF melter feed preparation.

\section{TABLE I. Noble Metal Loading on CST}

\begin{tabular}{|c|c|c|}
\hline Metal & $\begin{array}{c}\text { Average } \\
\text { Loading } \\
(\mu \mathrm{g} / \mathrm{g} \text { CST })\end{array}$ & $\begin{array}{c}\text { Average } K_{d} \\
(\mathrm{ml} / \mathrm{g})\end{array}$ \\
\hline $\mathbf{R u}$ & 1.7 & 2.4 \\
\hline $\mathbf{R h}$ & 20.6 & 3.4 \\
\hline $\mathbf{P d}$ & 7.5 & 0.7 \\
\hline
\end{tabular}

The adsorption coefficient $K_{d}$ is calculated as:

$$
K_{d}=\frac{C_{0}-C_{f}}{C_{f}} \frac{V}{m}
$$


Westinghouse Savannah River Company

where $C_{0}$ is the initial concentration of metal in solution, $C_{f}$ is the final concentration, $V$ is the solution volume $(15 \mathrm{ml})$ and $m$ is the mass of CST in the vials $(5 \mathrm{~g})$.

\section{Preparation of CST for DWPF Melter Feed Process Simulations}

\section{Bench-Scale Hydrogen/Foaming Studies}

\section{CST Loading $^{2}$}

One of the technical concerns with the use of CST resin for Salt Alternatives is the adsorption of noble metals (Pd, $\mathrm{Rh}, \mathrm{Ru}$ ). It was postulated that the adsorption of these metals by a high surface area material (CST) could lead to significantly higher hydrogen production rates during melter feed preparation process operations. Small batch tests of 5 grams of CST in 16 grams of salt solution containing noble metals demonstrated that CST has the capability of adsorbing these noble metals (see Table I). Determination of the hydrogen generation rates, which would be expected during coupled operation, required the production of relatively large amounts of loaded CST for the experiments. To this end, it was decided to load 500 grams (110 deg C dry basis) to levels of cesium and noble metals expected in plant operations. Operation of a scaled CST ionexchange column in the manner proposed for full scale operation was found to be prohibitive from a time (30 days operation), and waste generation ( 2000 column volumes of salt), standpoint. Therefore, an alternative mode of operation was decided upon.

Loading of the CST resin was performed in an up-flow fluidized-bed column (2" in diameter by 24 " in height) to provide good mixing of salt solution and CST resin. The bed of solids was expanded to about $100 \%$ expansion. A smaller volume of salt solution was recirculated through the column. Salt solution makeup was based upon the "average" composition presented in WSRC-TR-99-00116 Rev. 0. (Ref. 2). The concentrations of cesium and potassium were increased to that representing the total that 500 grams of CST could adsorb while leaving the final concentrations of cesium and potassium in the salt at nominal design basis levels. Operation in this manner was judged to produce loaded $2 S T$ in equilibrium with fresh incoming salt solution. Noble metals concentrations from the Enhanced Comprehensive Catalyst (ECC) Ref. 3 study were used. Table II presents the salt recipe for loading 500 grams of CST with 6 liters of salt solution.

Figure 11 presents the experimental setup for loading the 500 grams of CST. Operation of the column entailed the following steps (See ITS/TNX Procedure Manual L27 Procedure 1.14 Rev. 0 for details):

1) Humid air treatment of CST. ( 24 hours)

2) Flush of CST fines with water. (1 hour)

3) Caustic pre-treatment with 2 molar $\mathrm{NaOH}$ and soak. ( 14 hours)

\footnotetext{
${ }^{2}$ The UOP CST Lot \# for these runs was: 999098810005
} 
4) CST loading with salt solution and soak over night. ( $\sim 3$ days)

5) Caustic flush of CST column. (1 hour)

6) Water flush of CST column. (1 hour)

7) Removal and air drying of CST solids.

TABLE II CST Loading Salt Solution Makeup for Bench-Scale Process Simulations Target Volume - 6 Liters

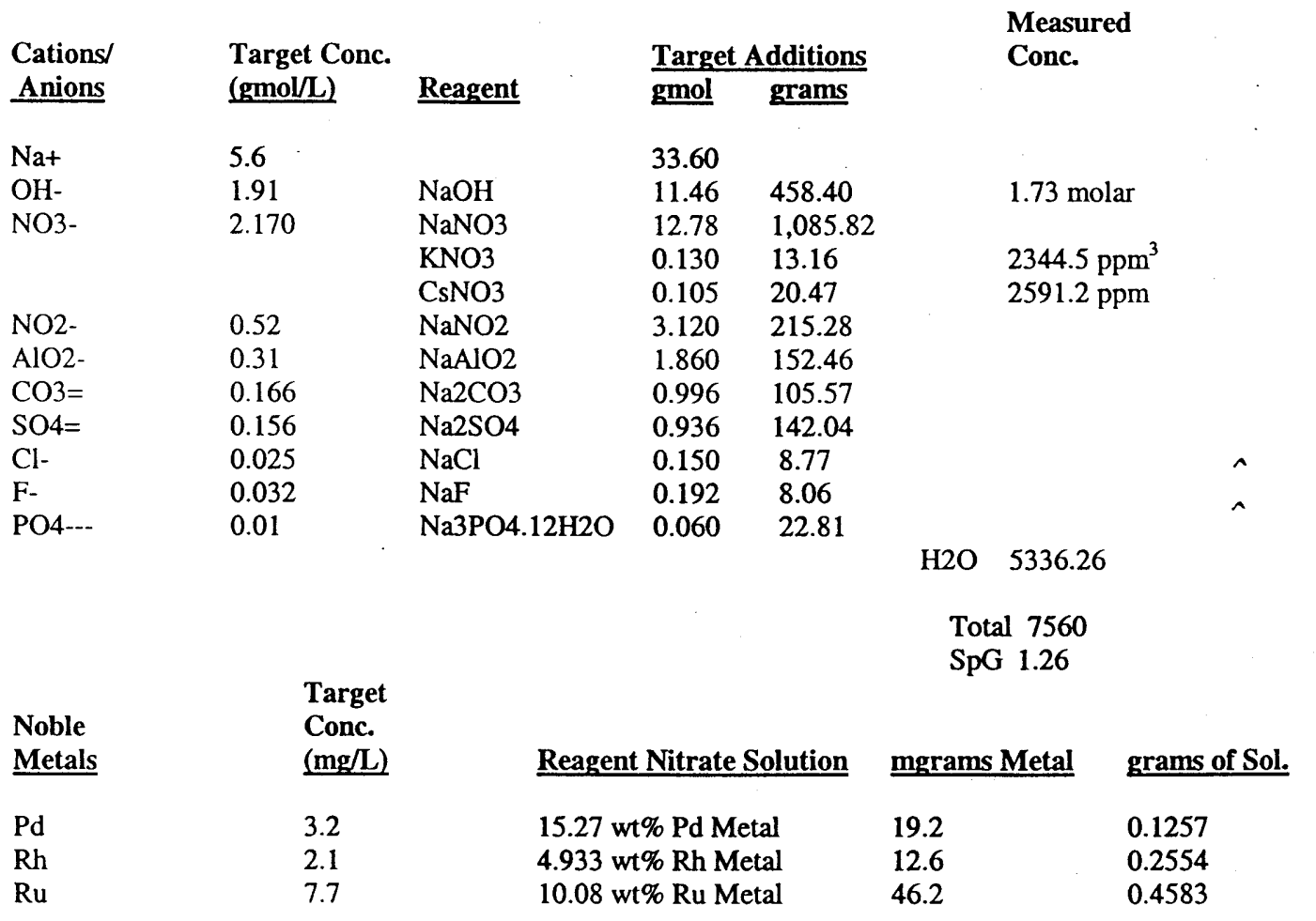

The initial moisture content of the CST was determined by drying at $110 \mathrm{deg}$ C to be $5.137 \mathrm{wt} \%$. Therefore, on a dry basis 527.33 grams of CST was charged to the loading column. The mass of air-dried loaded CST recovered was 638.25 grams. This represented a $21.03 \%$ increase in mass, (likely mostly water). Drying of the loaded CST at $610 \mathrm{deg}$ C to determine the oxide content resulted in a $22.78 \%$ lose; i. e., $77.22 \mathrm{wt} \%$ of the CST was oxide. Final cesium content of the salt solution was determined to be $35.09 \mathrm{ppm}$. This represents a $>99 \%$ drop from its initial concentration of $2591 \mathrm{ppm}$. Analytical data in Table III demonstrates that most of the adsorption process takes place in the first 8 hours of operation. Potassium is also adsorbed, but to a much lesser extent.

\footnotetext{
${ }^{3}$ Analysis for potassium ion was about $3 \mathrm{X}$ target due to suspected potassium contamination of sodium nitrate reagent used.
} 


\section{TABLE III CST Cesium Loading Rate Data}

$\begin{array}{lrcc} & \begin{array}{c}\text { Cesium } \\ \text { (ppm) }\end{array} & \begin{array}{c}\text { Potassium } \\ \text { (ppm) }\end{array} & \begin{array}{c}\text { Hydroxide } \\ \text { (Molar) }\end{array} \\ \text { Initial Salt Solution Conc. (filtered) } & 2591.2 & 2344.5 & 1.73 \\ \text { Initial Salt Solution Conc. (un-filtered) } & 2333.7 & 2140.2 & 1.68 \\ \text { Salt Solution after first 8 hours } & 54.1 & & \\ \text { Salt Solution after second 8 hours } & 31.1 & & \\ \text { Salt Solution after third 8 hours } & 21.1 & & 1.67 \\ \text { Final Salt Solution } & 35.1 & 1790.4 & 1.1\end{array}$

\section{Size Reduction of Loaded CST for Bench-Scale Hydrogen/Foaming Studies}

One of the small scale CST hydrogen study runs required a $10 \mathrm{wt} \%$ slurry of loaded CST reduced in size to that comparable to frit. The size reduction was performed using the CST Grinding and Classification Setup depicted in Figure 8. The system was operated in a batch mode with 140 grams of loaded CST in $1400 \mathrm{ml}$ of water.

\section{Pilot-Scale Hydrogen/Foaming Studies}

\section{CST Loading ${ }^{4}$}

A larger scale version of the CST loading setup was built in order to load large quantities of CST in a manner similar to the small-scale operation. Figure 12 presents a drawing of this equipment. The scale factor for this column was 15 compared to the smaller column (i.e. 7500 grams of CST - 110 deg C dry basis) was loaded with 90 liters of salt solution. Salt solution component concentrations were maintained at the levels prepared for the smaller scale run. Table IV presents the salt solution makeup for these runs. Two 45-liter charges of salt solution were used for each CST batch. Table V presents the analysis of the combined salt solution for the two batches. Two CST batches were required to meet the loaded CST requirements for the larger scale hydrogen/foaming studies to be performed in the Glass Feed Preparation System (GFPS). See ITS/TNX Procedure Manual L27 Procedure 1.20 Rev. 0 for details.

\footnotetext{
'The UOP CST Lot \# for these runs was: 999098810006
} 


\section{TABLE IV CST Loading Salt Solution Makeup for Pilot-Scale Process Simulations}

Target Volume -45 Liters

\begin{tabular}{|c|c|c|c|c|c|}
\hline \multirow{2}{*}{$\begin{array}{l}\text { Cations } \\
\text { Anions } \\
\end{array}$} & \multirow{2}{*}{$\begin{array}{c}\text { Target } \\
\text { Conc. } \\
(\mathrm{gmol} / \mathrm{L})\end{array}$} & \multicolumn{3}{|c|}{ Target Additions } & \\
\hline & & $\underline{\text { Reagent }}$ & gmol & grams & \\
\hline $\mathrm{Nat}$ & 5.6 & & 252.0 & & \\
\hline $\mathrm{OH}-$ & 1.91 & $\mathrm{NaOH}$ & 85.95 & 3438.00 & \\
\hline \multirow[t]{3}{*}{ NO3- } & 2.170 & $\mathrm{NaNO} 3$ & 95.82 & $8,143.61$ & \\
\hline & & KNO3 & 0.977 & 98.73 & \\
\hline & & CsNO3 & 0.81 & 157.88 & \\
\hline NO2- & 0.52 & $\mathrm{NaNO} 2$ & 23.40 & $1,614.60$ & \\
\hline $\mathrm{AlO} 2-$ & 0.31 & $\mathrm{NaAlO} 2$ & 13.95 & $1,143.48$ & - \\
\hline $\mathrm{CO} 3=$ & 0.166 & $\mathrm{Na} 2 \mathrm{CO} 3$ & 7.470 & 791.75 & \\
\hline SO4= & 0.156 & $\mathrm{Na} 2 \mathrm{SO} 4$ & 7.020 & 997.12 & \\
\hline $\mathrm{Cl}-$ & 0.025 & $\mathrm{NaCl}$ & 1.125 & 65.75 & \\
\hline F- & 0.032 & $\mathrm{NaF}$ & 1.440 & 60.47 & \\
\hline \multirow[t]{5}{*}{ PO4--- } & 0.01 & $\mathrm{Na} 3 \mathrm{PO} 4.12 \mathrm{H} 2 \mathrm{O}$ & 0.450 & 171.05 & \\
\hline & & $\mathrm{H} 2 \mathrm{O}$ & & $40,017.56$ & \\
\hline & & & Total & 56,700 & \\
\hline & & & $\mathrm{SpG}$ & 1.26 & \\
\hline & Target & & & & \\
\hline Noble & Conc. & & & & ค \\
\hline Metals & $(\mathrm{mg} / \mathrm{L})$ & \multicolumn{2}{|c|}{$\underline{\text { Reagent Nitrate Solution }}$} & mgrams Metal & grams of Sol. \\
\hline $\mathrm{Pd}$ & 3.2 & \multicolumn{2}{|c|}{15.27 wt\% Pd Metal } & 144.0 & $0.9430^{\circ}$ \\
\hline $\mathrm{Rh}$ & 2.1 & \multicolumn{2}{|c|}{$4.933 w t \%$ Rh Metal } & 94.5 & 1.9157 \\
\hline $\mathrm{Ru}$ & 7.7 & \multicolumn{2}{|c|}{10.08 wt\% Ru Metal } & 346.5 & 3.4375 \\
\hline
\end{tabular}

\section{TABLE V CST Loading Salt Solution Analysis}

$\begin{array}{cll}\text { Cations } & \text { Batch 1 } & \text { Batch 2 } \\ \text { Cs } & \text { 2030 ppm } & \\ \text { K } & 2212 \mathrm{ppm} & \text { 1875.6 ppm } \\ \text { Pd } & 3.0 \mathrm{ppm} & 2.8 \mathrm{ppm} \\ \text { Rh } & 1.9 \mathrm{ppm} & 1.8 \mathrm{ppm} \\ \text { Ru } & 5.3 \mathrm{ppm} & 5.4 \mathrm{ppm}\end{array}$

The $110 \mathrm{deg} C$ moisture content of the as-received CST was determined to be $8.373 \mathrm{wt} \%$. This led to an as-received CST charge to the 4 " column of 8185 grams. The column was operated similar to the small scale-loading column described above.

Batch 1

CST recovered from the column was air-dried and the weight determined to be 8214 grams. Some CST resin was left behind in the column and was removed with the second batch by disassembly of the column. Drying of the CST from the first 4" column run at $600 \mathrm{deg}$ C resulted in a $16.15 \%$ loss (i.e. $83.87 \mathrm{wt} \%$ was oxide). 


\section{Batch 2}

In this run 500 grams additional CST was added to the column to allow sampling of the product solids. This resulted in a total CST charge for this run of 8687.1 grams. The column was disassembled after the run to recover all the solids. The mass of the air-dried CST recovered from batch 2 was 8892 grams. Drying of the CST from the second 4" column run at $600 \mathrm{deg}$ C resulted in a $14.19 \%$ loss (i.e. $85.81 \mathrm{wt} \%$ was oxide). Samples of the salt solution were taken during this run to determine the cesium adsorption kinetics. Figure 13 presents these results.

Note: Water left in the column after the final water flush allowed the solids to flow readily from the column to sieve trays via valve V-5. The flow could be stop and restarted without plugging of the $3 / 8$ inch diameter drain line.

\section{Size Reduction of CST for GFPS Hydrogen/Foaming Studies}

Size reduction of loaded CST from Batch 1 of the 4" loading column was performed in the equipment presented in Figure 8 . The system was operated in a semi-continuous manner with periodic additions of CST and water with removal of product CST slurry. The required mass of CST on an oxide basis for the GFPS run was 5130 grams. This equated to 6120 grams of airdried CST based upon an oxide content of $83.87 \mathrm{wt} \%$. An additional 100 grams was added to this total to account for sampling and loses. A sample for particle size analysis taken about $2 / 3$ of the way through the size reduction process demonstrated that particles larger than the required $\rightarrow$ 80 mesh size were in the product slurry. This was attributed to the build-up of fine particles in * the light ends, which would increase the density, and the viscosity of the fluid. Both factors would lead to larger particles being floated out of the inner column. Without a means to account for this effect, it was decided to wet sieve the product slurry through 80 -mesh screen, with particles greater than 80 mesh being recycled to the size reduction equipment. Five 8 -liter carboys of CST slurry were produced totaling 37,693.2 grams. Additional water would be needed to flush each of the carboys during their addition to the GFPS.

\section{CONCLUSIONS}

1) A CST particle size range comparable to the Frit 202 (80-200 mesh) will give comparable hydrodynamic properties.

2) CST particle size can be reduced by exposure to a high sheer environment like a centrifugal pump, but reducing the CST size distribution to the required $80-200$ mesh would require extended periods of operation.

\section{RECOMMENDATIONS}

1) If CST is the process selected, investigate in-line size reduction and classifying of the CST as it is removed from the ion exchange columns. 
Immobilization Technology Section

WSRC-TR-99-00244

Savannah River Technology Centeŕ

Revision 0

Westinghouse Savannah River Company

\section{REFERENCES}

1) W. B. Van Pelt and M. R. Poirier, Transport and Storage Properties of CST Slurries, SRT-WHM-98-0019

2) D. D. Walker, Preparation of Simulated Waste Solutions, WSRC-TR-99-00116, Rev. 0

3) C. L. Crawford, Decomposition Studies of Tetraphenylborate Slurries (U), WSRC-TR-97-0046, Rev. 0 


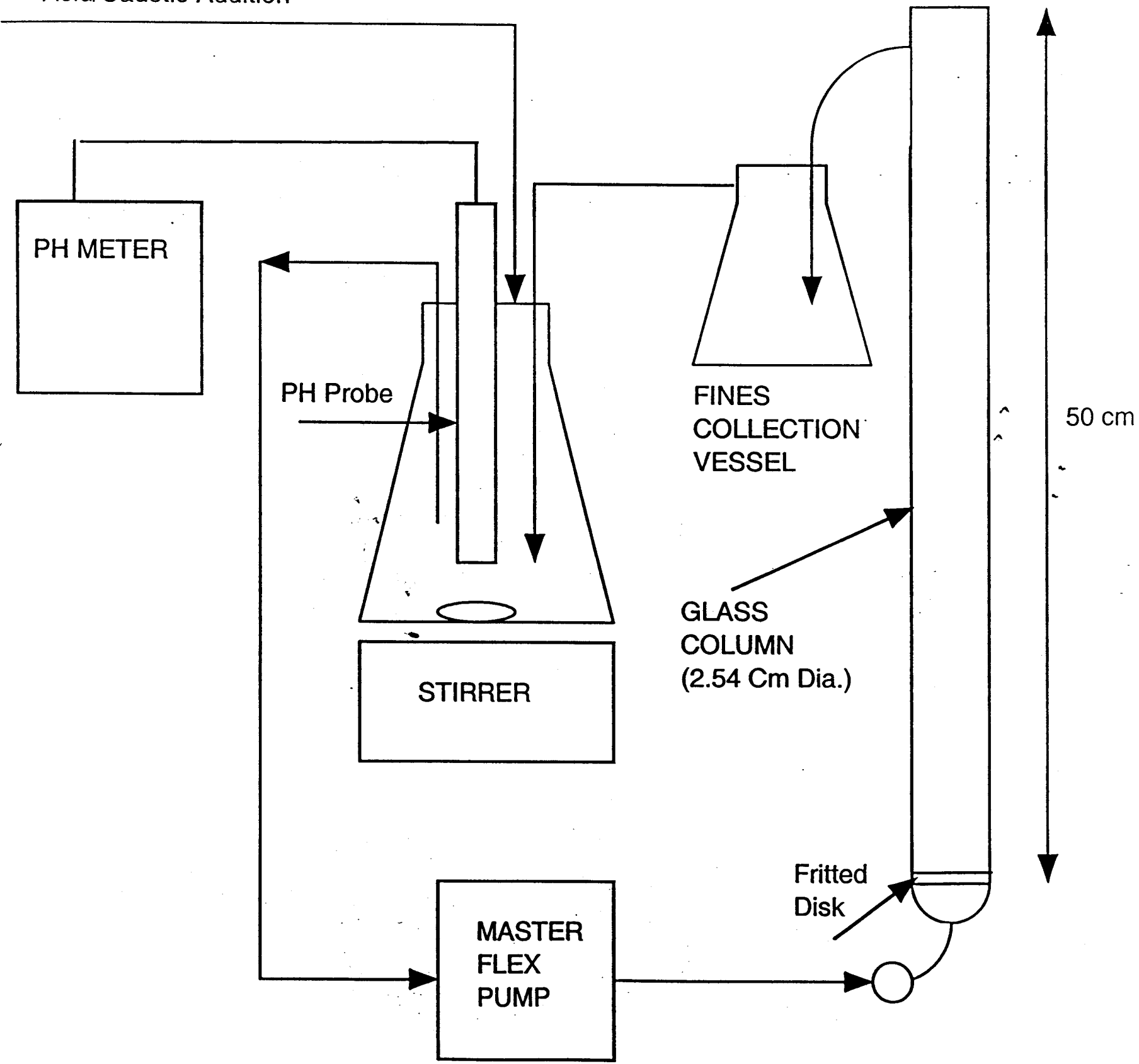

Figure 1. Experimental Setup For CST and Frit Settlina Studies 


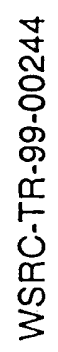
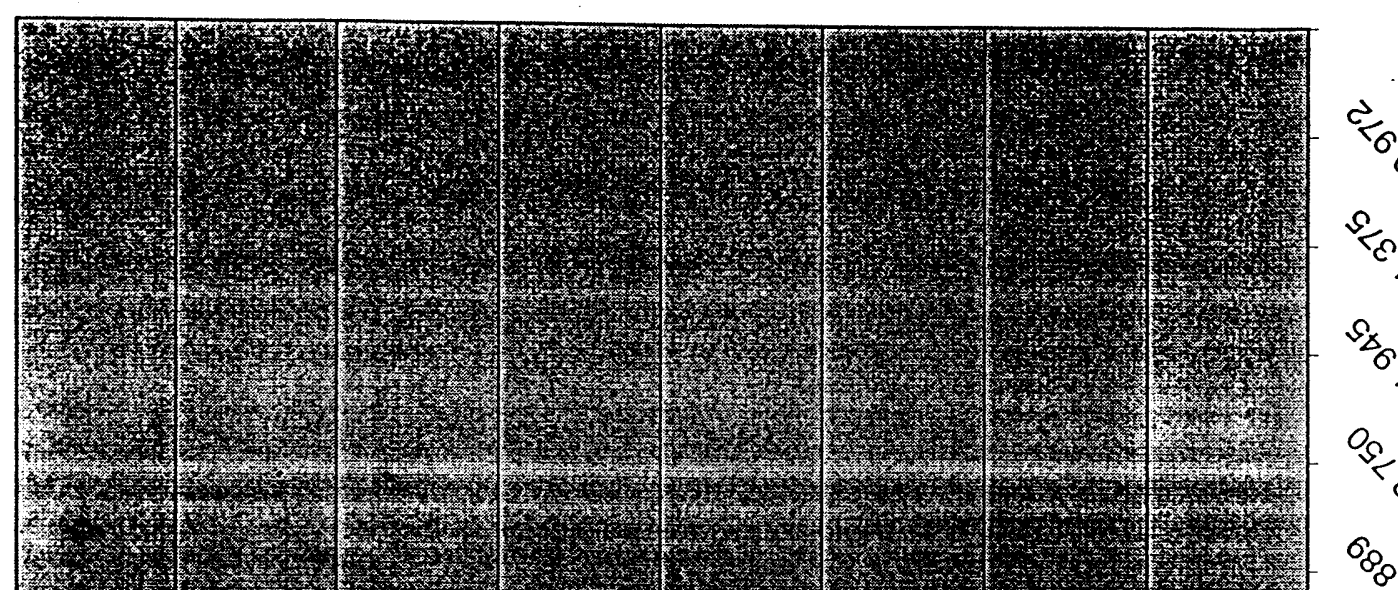

㩆

츰

동 ㅇํㅇ

心

종응

응 등

동워 둥

$\vdash \infty$

동

N

言突

우

q

ㅇ.

เั

요

$\%+M$

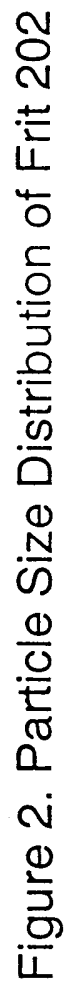




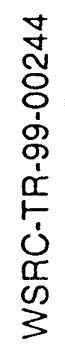

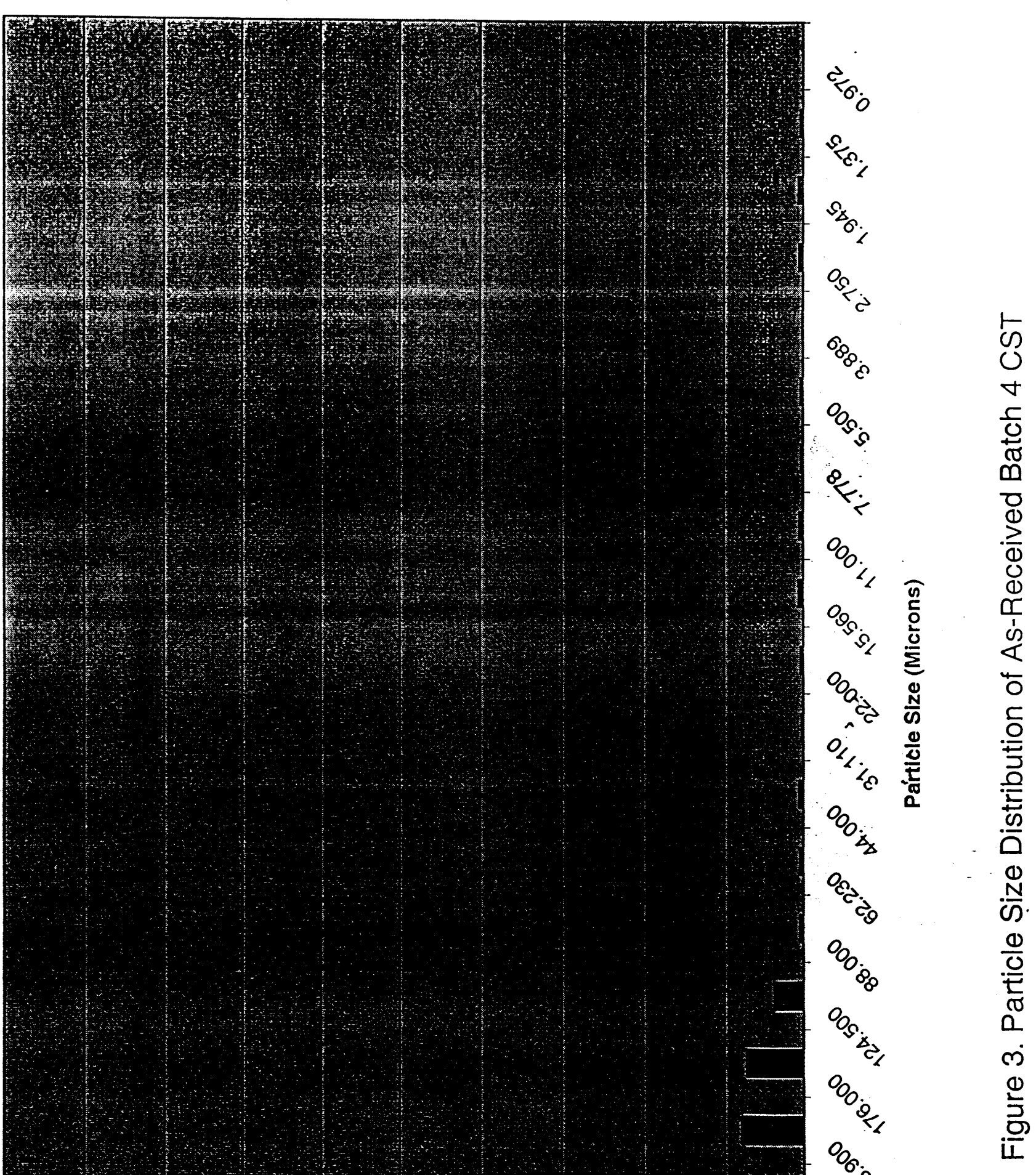

등 농 ㅇํㅇ

क 仓

항응

응 동 돈

는

을 变

Nㅡㅎ듬

응 ญํํㅇ

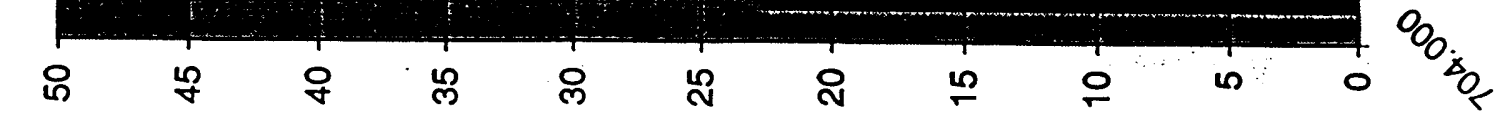

$\%+M$ 


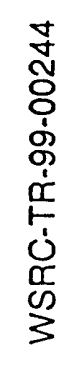
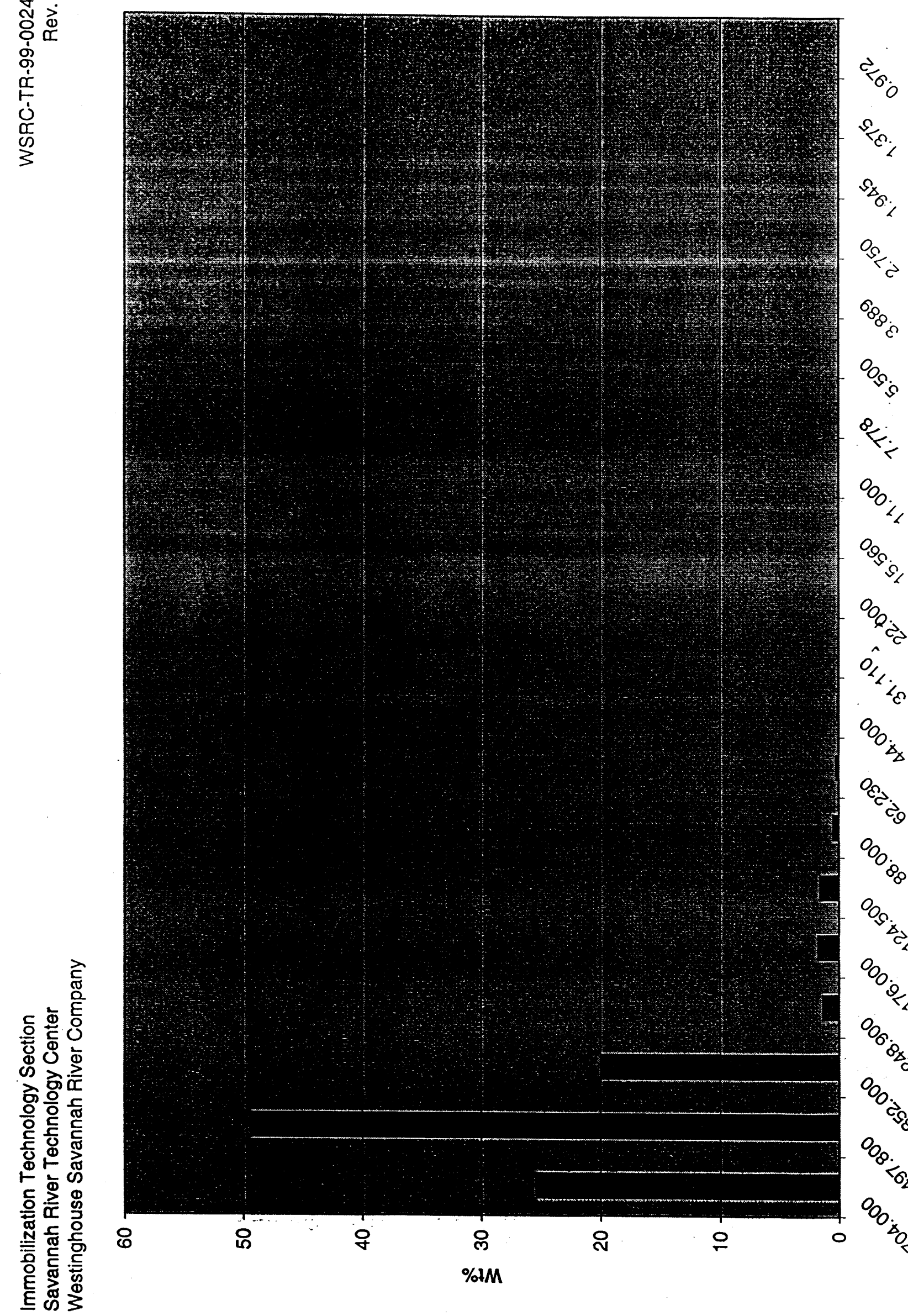


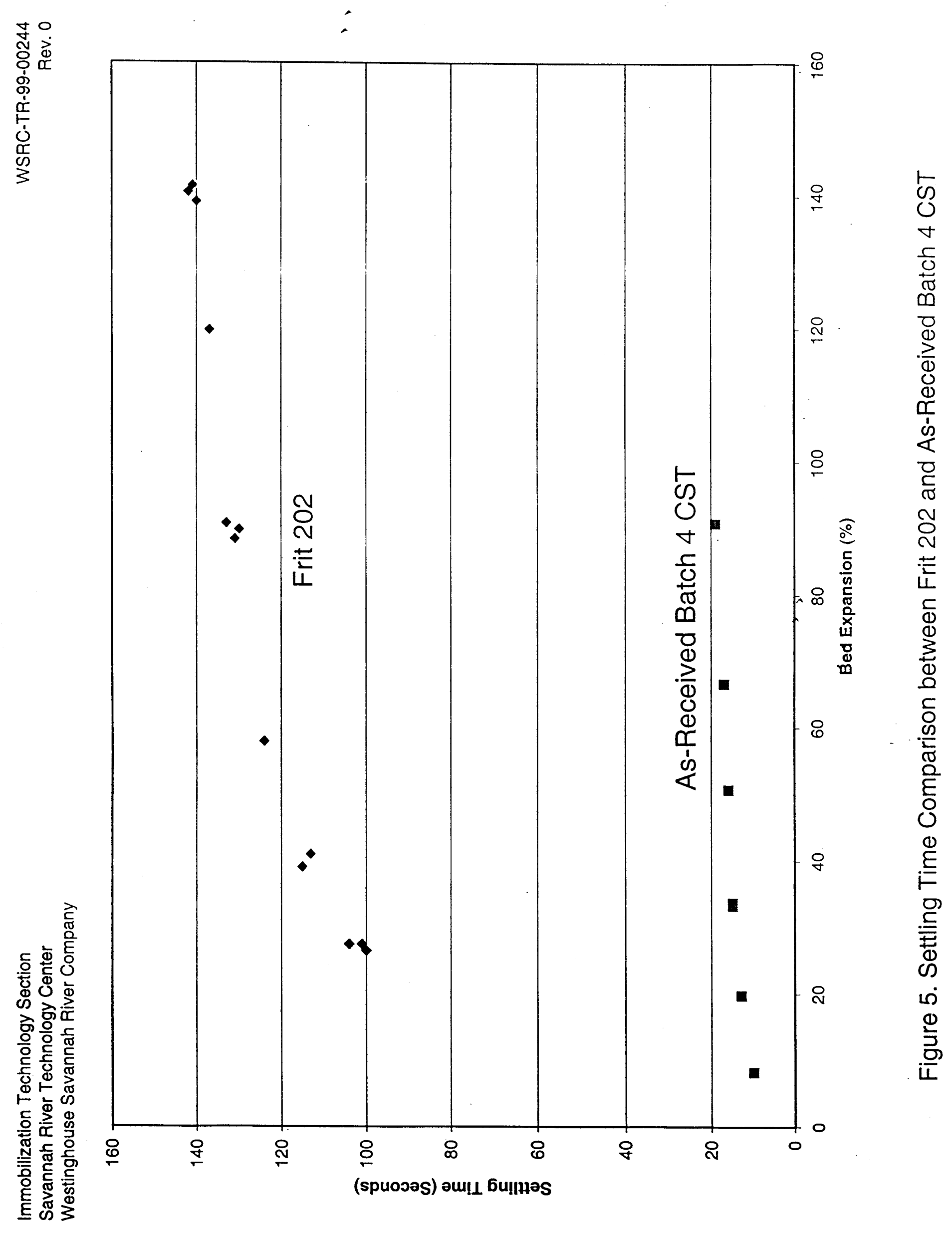




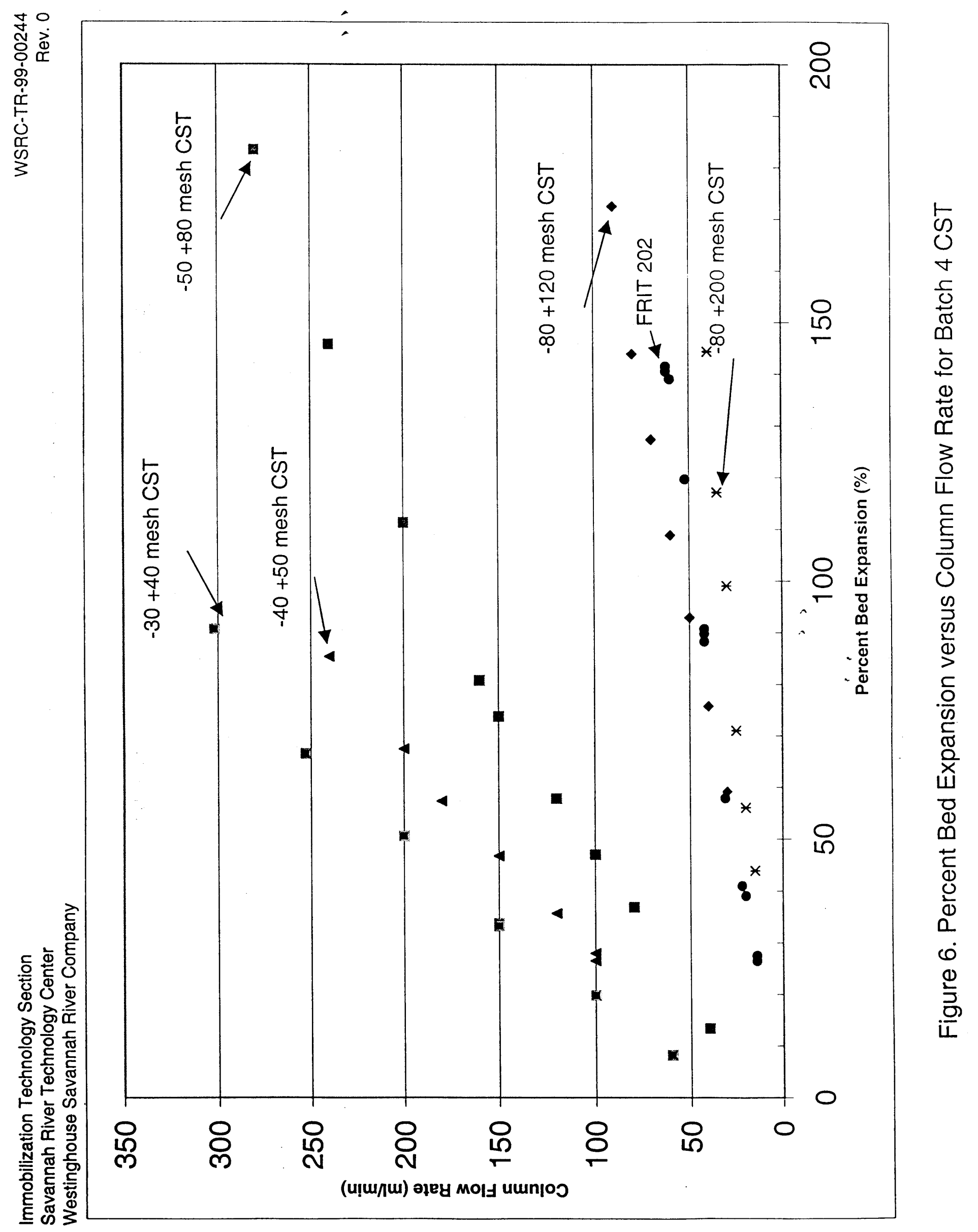




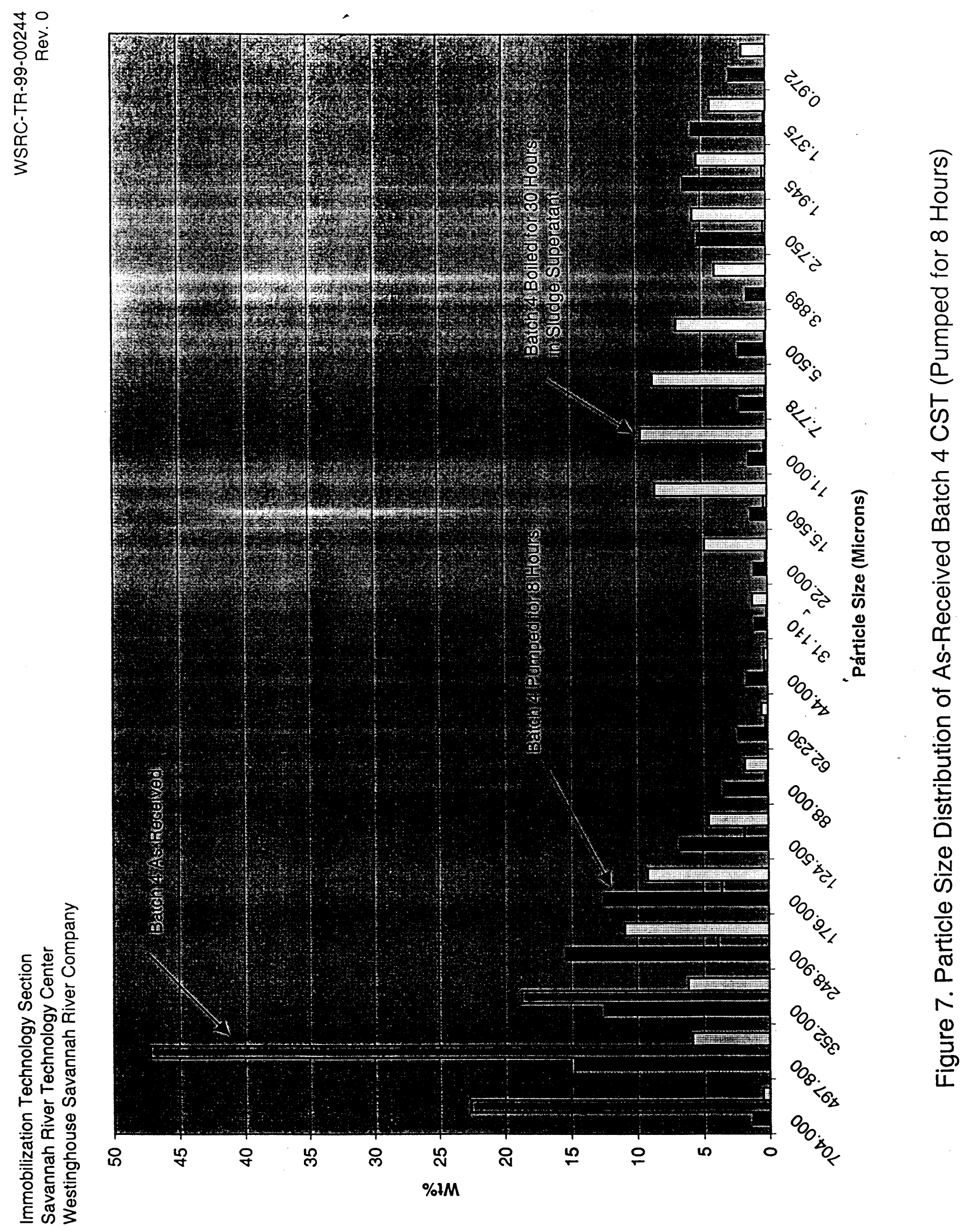


Immobilization Technology Section

Savannah River Technology Center '

WSRC-TR-99-00244

Westinghouse Savannah River Comṕany

Rev. 0

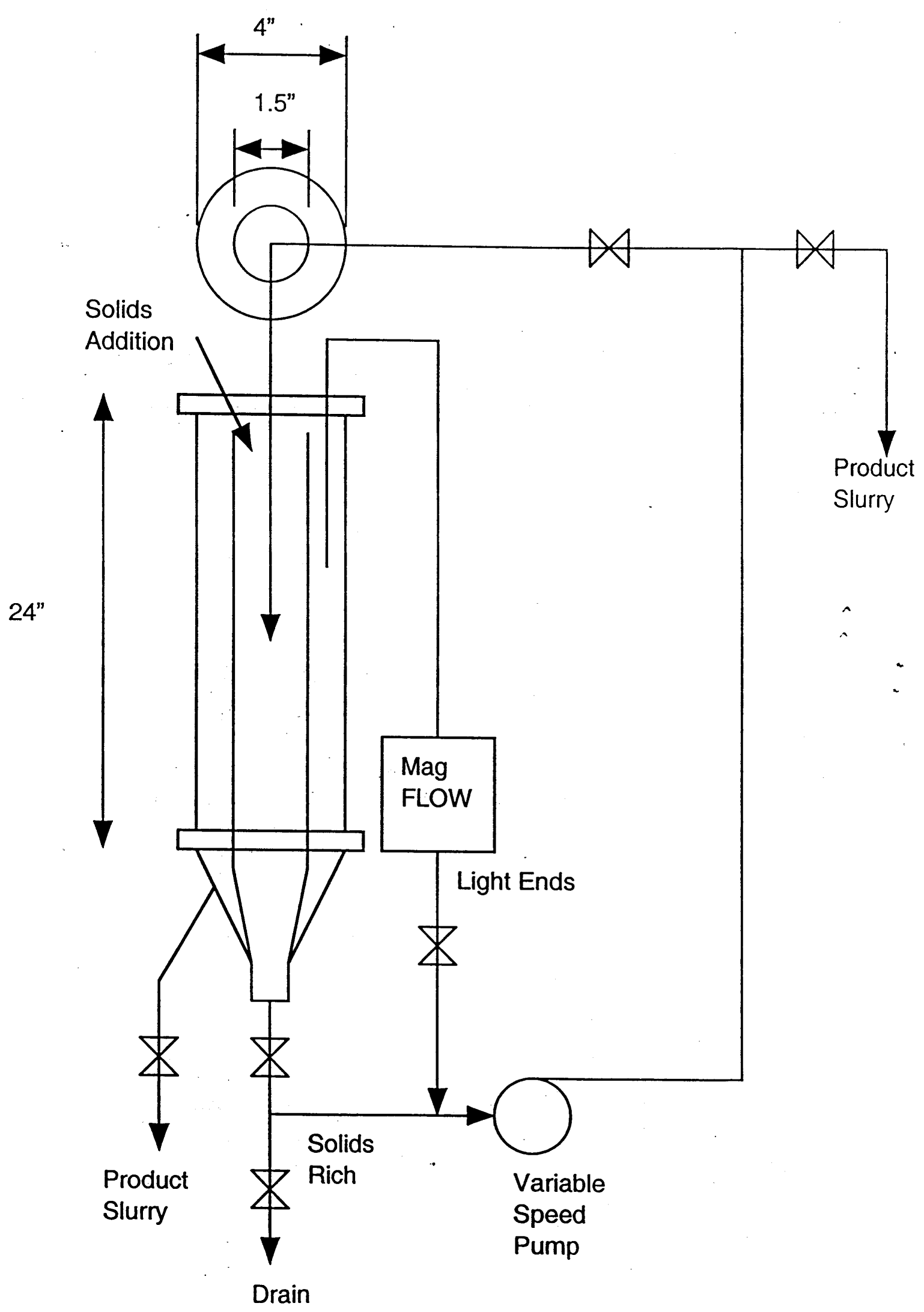



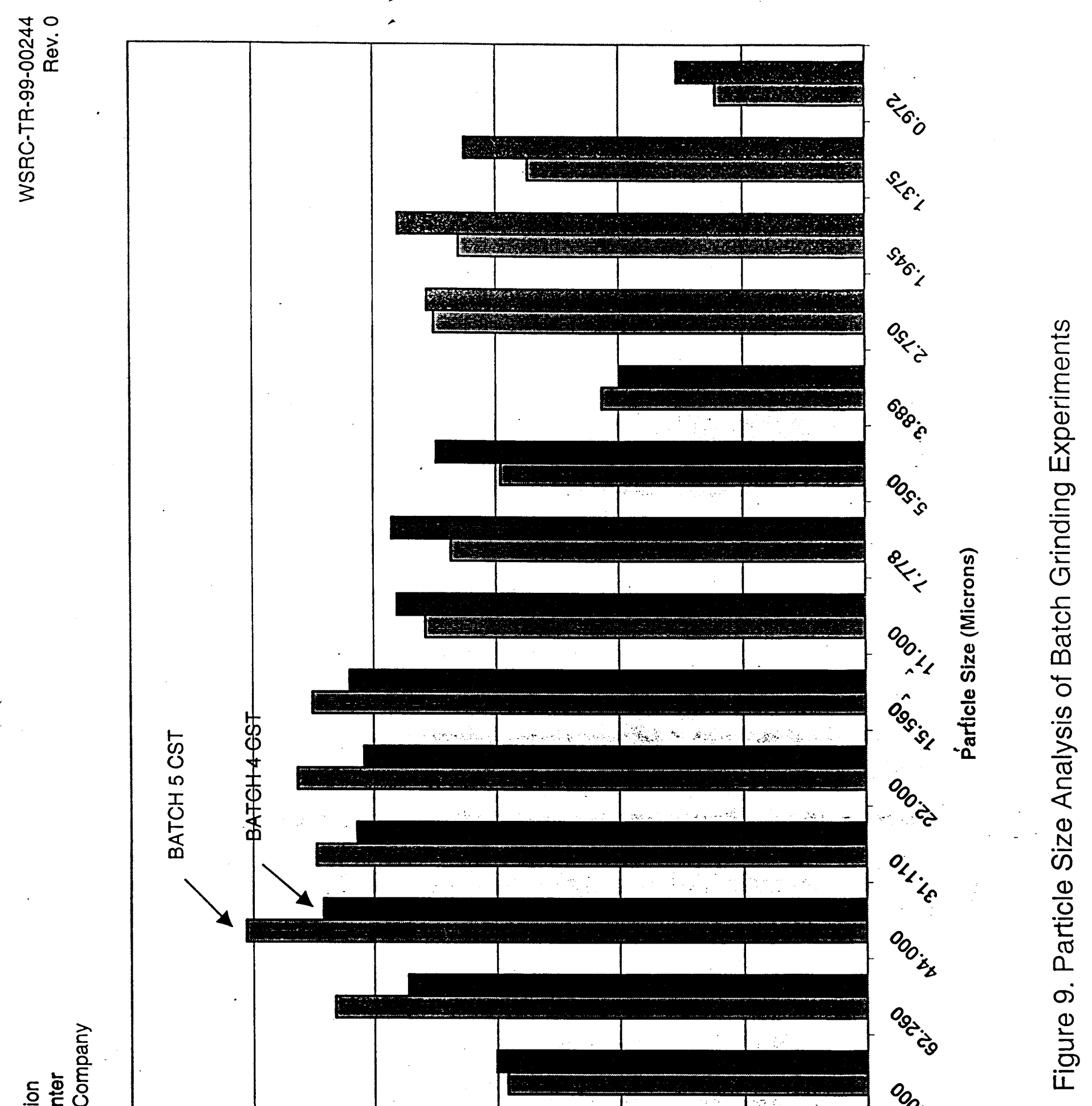

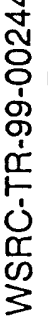

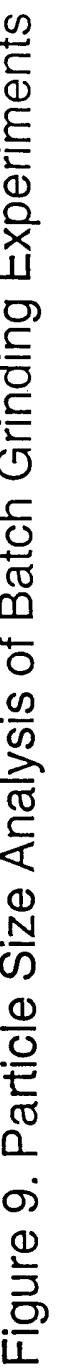




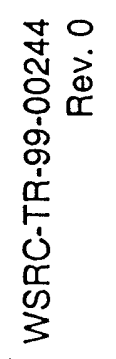
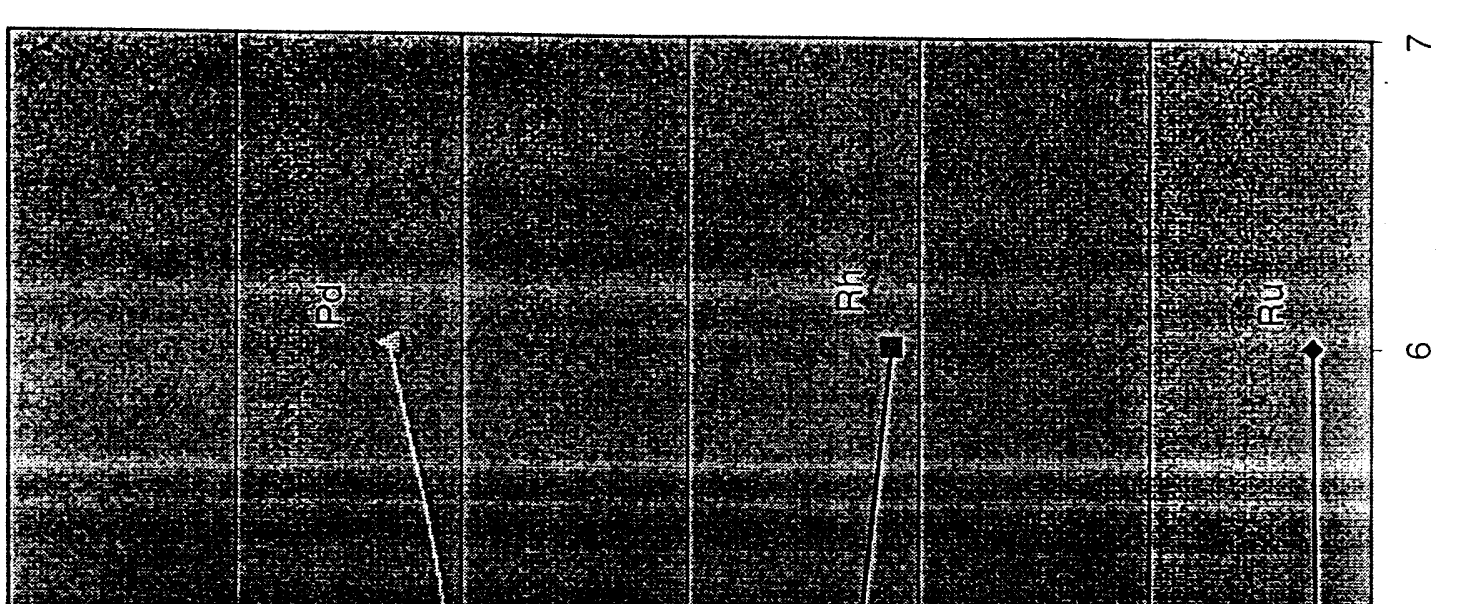

$\omega$ (mdd) uo!̣en\}uәsuos 

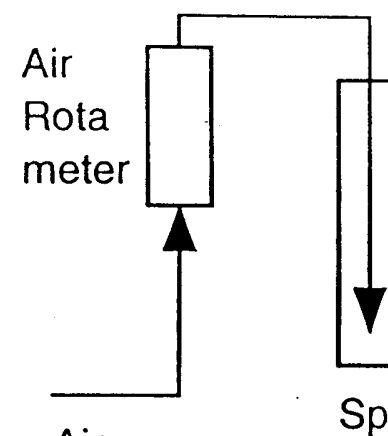

Humid Air

Air Sparge

Valve Position

3-Way

I Air Purge Valve Position

V-3

Overflow

Tubing

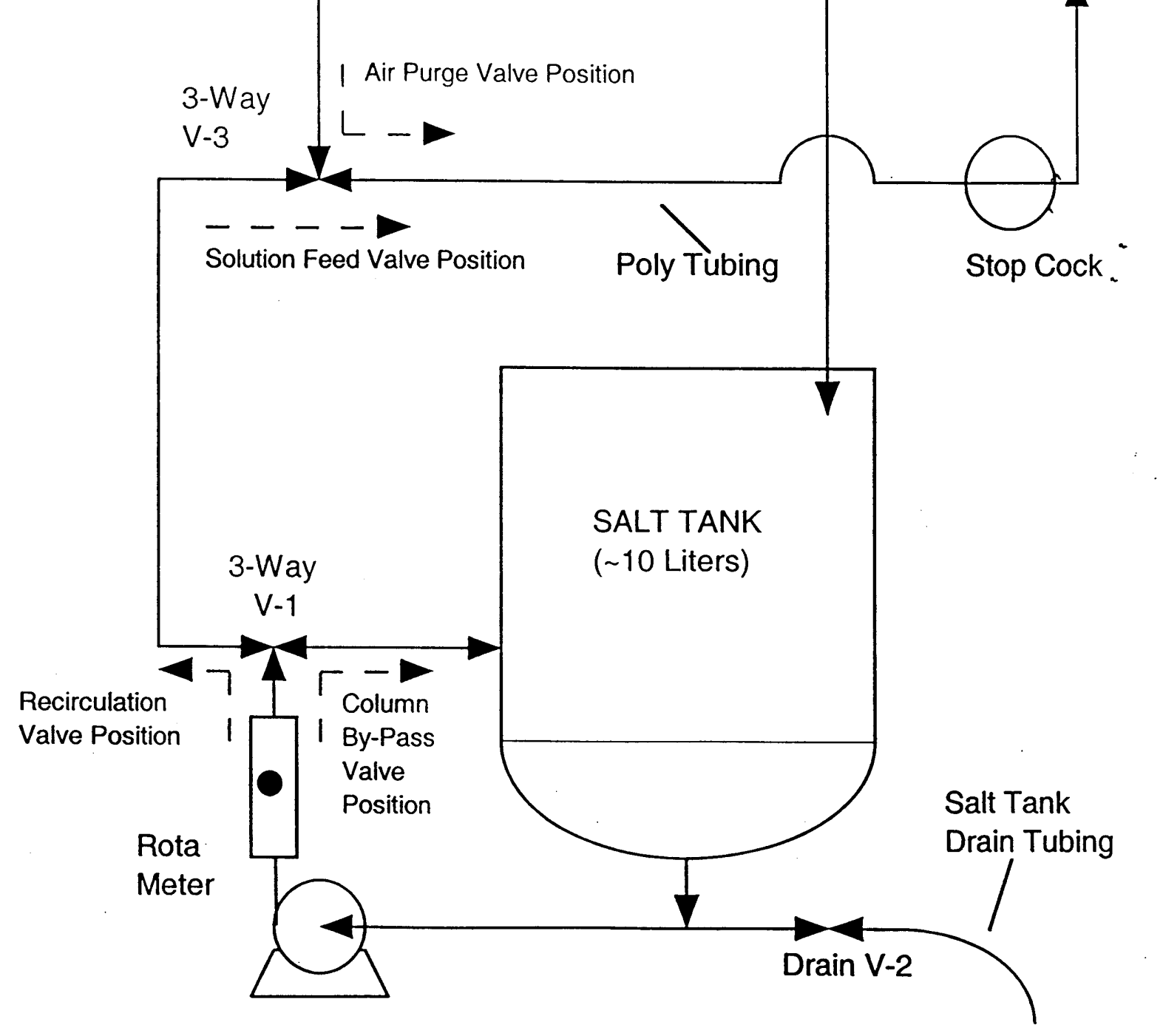




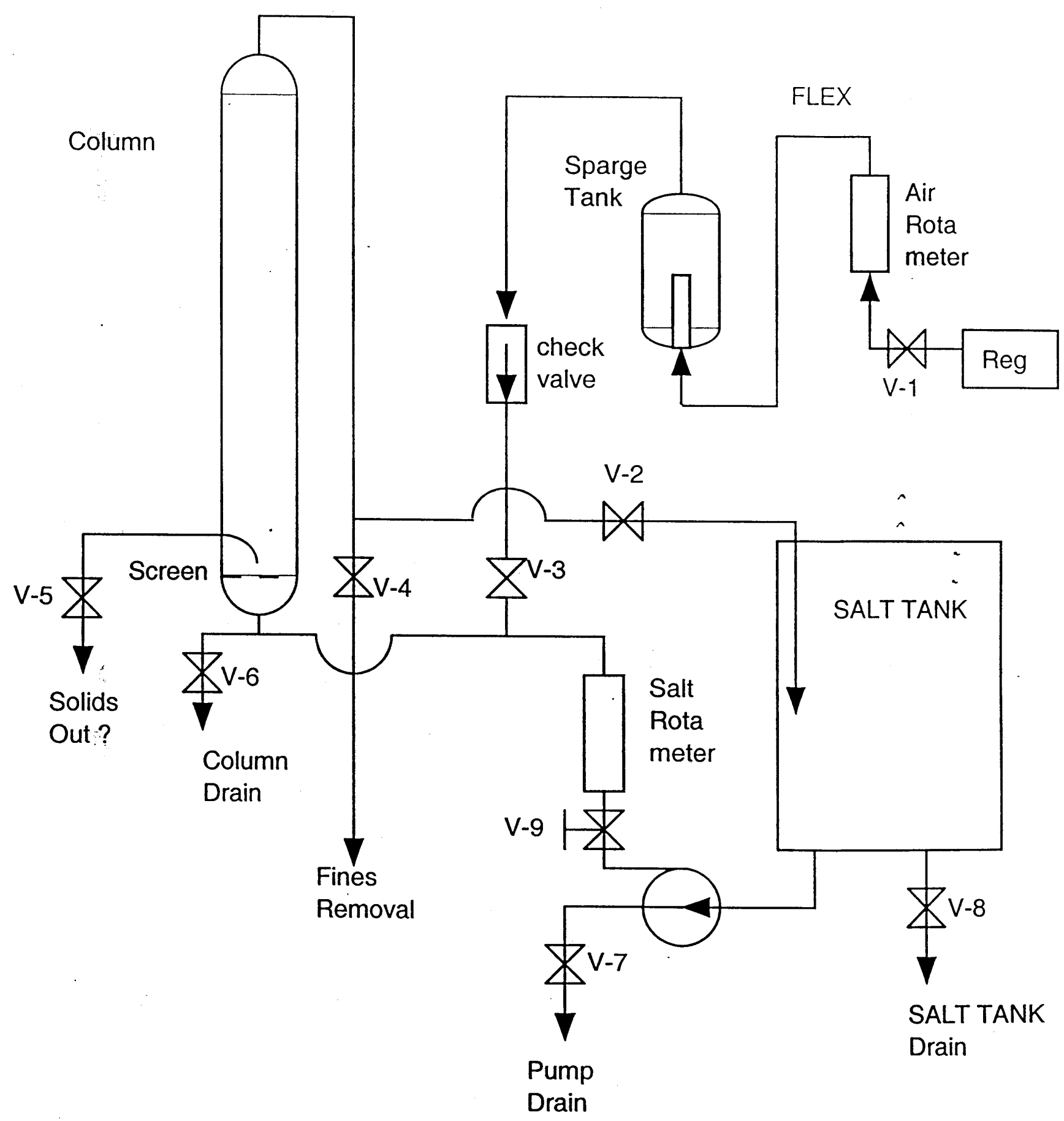

Figure 12. Four Inch Diameter CST Loading Column 


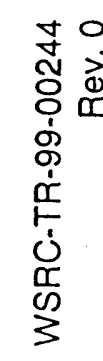

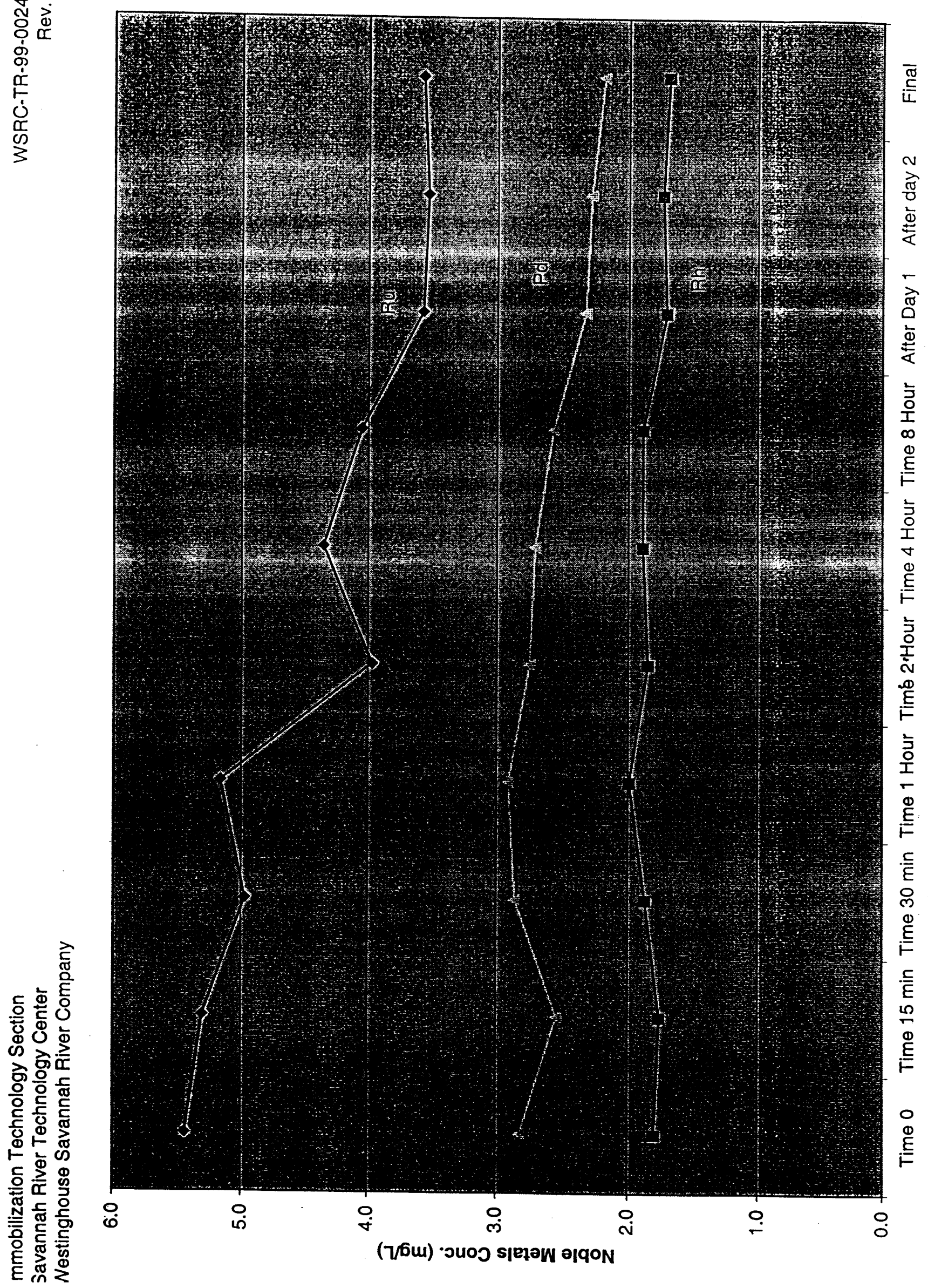

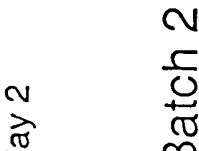

$\infty$

安

ते

可

흐

고

F

क

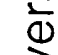

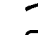

등

응

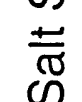

.

-

- 음

$\underline{\underline{\underline{E}}}$

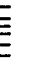

요

ब

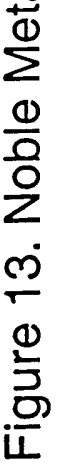

